\author{
Anna Zellma ${ }^{1}$ \\ Uniwersytet Warmińsko-Mazurski w Olsztynie \\ Wydział Teologiczny \\ Edward Wiszowaty ${ }^{2}$ \\ Uniwersytet Warmińsko-Mazurski w Olsztynie \\ Wydział Teologiczny \\ Wyższa Szkoła Policji w Szczytnie
}

\title{
Przepowiadanie homilijne i katechetyczne w kontekście regionalnym
}

W ostatnich latach jesteśmy świadkami szybko postępujących zmian w sferze życia społecznego, kulturalnego, moralnego i religijnego. Daje się przy tym zauważyć różne inicjatywy obywatelskie podejmowane w środowisku lokalnym oraz wzrost zainteresowania tym, co rodzime, bliskie ludziom, związane z ich sytuacją życiową, miejscem zamieszkania, życia i pracy oraz kulturą własnego regionu. Często procesy te są wyrazem ujawniających się tendencji społecznych związanych z poszukiwaniem, odtwarzaniem lub rekonstruowaniem tożsamości regionalnej i tradycji regionalnych oraz promocją idei „małych ojczyzn” i dziedzictwa regionalnego. Wzrost zainteresowania kulturą regionalną w jej wielorakich wymiarach, w tym dobrami materialnymi i duchowymi regionu, wartościami, jakich nośnikiem jest ta kultura, własnymi korzeniami rodzinnymi, wiąże się wprost z ideą i programem regionalizmu. Wobec tych procesów nie mogą być obojętne osoby, które głoszą słowo Boże. Proces przepowiadania słowa Bożego wymaga zarówno ciągłej konfrontacji z konkretnymi sytuacjami adresatów ${ }^{3}$, jak też uwzględniania kultury danego obszaru oraz wartości zawartych w tradycji kulturowej i w kulturze współczesnej ${ }^{4}$.

${ }^{1}$ Anna Zellma - profesor nauk teologicznych; kierownik Katedry Teologii Pastoralnej i Katechetyki na Wydziale Teologii UWM w Olsztynie.

${ }^{2}$ Ksiądz Edward Wiszowaty - profesor nauk teologicznych; pracownik Wydziału Teologii Uniwersytetu Warmińsko-Mazurskiego w Olsztynie i Wyższej Szkoły Policji w Szczytnie.

3 Trudno nie zgodzić się ze stwierdzeniem ewangelickich homiletyków Achima Härtnera i Holgera Eschmanna, że kościelna mowa staje się przepowiadaniem właśnie poprzez konkretne ukierunkowanie na słuchających w danej chwili. A. Härtner, H. Eschmann, Predigen lernen. Ein Lehrbuch für die Praxis, Göttingen 2008, s. 19.

${ }^{4}$ DOK 212. 
Wyżej zasygnalizowana sytuacja rodzi określone wyzwania w zakresie różnych typów przepowiadania słowa Bożego. Warto zatem poszukiwać odpowiedzi na pytania: jaką rolę w przepowiadaniu homilijnym i katechetycznym odgrywa kontekst regionalny? Do jakich treści z zakresu kultury regionalnej warto odwoływać się głosząc Ewangelię? W jaki sposób to czynić? Odpowiedź na te pytania nie jest możliwa bez wyjaśnienia terminologii podstawowej dla problematyki określonej w tytule. Stąd też najpierw zostanie krótko wyjaśnione, co rozumiemy, używając terminów „,przepowiadanie homilijne”, ,przepowiadanie katechetyczne”, „kontekst regionalny”. Następnie wskaże się na treści kultury regionalnej, do których warto odwoływać się w przepowiadaniu homilijnym i katechetycznym, gdyż są one nośnikiem wartości duchowych. W toku dalszych analiz zwróci się uwagę na sposoby realizacji tak ukierunkowanego przepowiadania.

\section{Ustalenia terminologiczne}

Przystępując do przedstawienia problematyki określonej w tytule niniejszego opracowania, warto zaznaczyć, że zarówno kwestie związane z rozumieniem przepowiadania homilijnego i katechetycznego, jak też regionalizmu, są szeroko i wieloaspektowo analizowane we współczesnej polskiej literaturze. Co charakterystyczne, możemy spotkać się z różnymi definicjami tych terminów. Uzasadnia to zatem potrzebę określenia przyjętego przez nas rozumienia przepowiadania homilijnego i katechetycznego.

Niewątpliwie termin ,przepowiadanie homilijne” wskazuje na jeden z podstawowych sposobów głoszenia słowa Bożego podczas liturgii. Homilia bowiem stanowi integralną część liturgii Mszy św. ${ }^{5}$. Wyjaśnia treść i symbolikę sprawowanego misterium ${ }^{6}$. Przepowiadanie homilijne bazuje na tekstach biblijnych, które przewidziano do czytania i rozważania na dany dzień roku liturgicznego oraz ewentualnie na innych tekstach z części stałych lub własnych Mszy św. z dnia? Na podstawie tych tekstów homilista nie tylko ma wyjaśniać treść i symbolikę sprawowanego misterium oraz tajemnice wiary i zasady życia chrześcijańskiego, ale także pomagać słuchaczom w pełnym zrozumieniu słowa Bożego, zachęcać do wyznawania wiary i wprowadzać do misji apostolskiej ${ }^{8}$. Interpretowane podczas homilii teksty biblijne winny zatem być jednocześnie odnoszone do życia

${ }_{5}^{5}$ DH 4-6. Zob. również: G. Siwek, Kiedy homilia, kiedy kazanie?, „Homo Dei” 76(2007) nr 4, s. 28-41; S. Dyk, Liturgia miejscem interpretacji słowa Bożego, „Zeszyty Naukowe Katolickiego Uniwersytetu Lubelskiego" 53(2010) nr 1, s. 33-46.

${ }^{6}$ Szerzej o tym zob. np. w: S. Dyk, Homilia - droga do żywego poznania misterium Chrystu$s a$, Kielce 2016.

7 KL 24, 50, 92; zob. także o tym np. w: E. Wiszowaty, Przepowiadanie homilijne w społeczeństwie medialnym, „Roczniki Teologiczne” 61(2014) z. 6, s. 153-157.

${ }^{8}$ VD 59. 
słuchaczy - ich potrzeb, zainteresowań, środowiska społecznego, pracy, nauki, kultury, w której żyją i której podlegają. Przepowiadanie homilijne wymaga odwołania do sytuacji życiowej słuchaczy oraz brania pod uwagę aspektu lokalnego i duszpasterskiego'.

$\mathrm{Z}$ uwagi na to, że przedmiotem analiz podjętych w niniejszym opracowaniu jest również przepowiadanie katechetyczne, istotne jest właściwe rozumienie także tego terminu. W niniejszym opracowaniu przepowiadanie katechetyczne oznacza jedną z form posługi słowa Bożego we wspólnocie Kościoła, która obejmuje „przekaz treści wiary (doktryn i norm moralnych)"10. Tak określone przepowiadanie katechetyczne znajduje się u podstaw działalności duszpasterskiej Kościoła. Realizuje się ono m.in. w rodzinie chrześcijańskiej, w różnych formach katechezy parafialnej adresowanej do dzieci, młodzieży dorosłych oraz w eklezjalnych wspólnotach i ruchach religijnych ${ }^{11}$. Przepowiadanie katechetyczne jest „kierowane do wierzących w Chrystusa i ochrzczonych. Dokonuje się przez systematyczny wykład prawd wiary i zasad życia chrześcijańskiego w celu ich lepszego zrozumienia i wprowadzenia słuchaczy w chrześcijaństwo" ${ }^{12}$. W przepowiadaniu katechetycznym jednym $\mathrm{z}$ istotnych kryteriów doboru treści jest aktualna sytuacja życiowa konkretnej grupy adresatów ${ }^{13}$.

Jak łatwo zauważyć, dla analiz podjętych w niniejszym opracowaniu ważne jest również rozumienie „kontekstu regionalnego". Termin ten nawiązuje do zespołu czynników społeczno-kulturalnych powiązanych z regionem i jego dziedzictwem kulturowym ${ }^{14}$. Terminem „kontekst regionalny” można posługiwać się m.in. w nawiązaniu do aktywności społecznej i kulturalnej, skoncentrowanej wokół pielęgnowania cech charakterystycznych dla danego regionu i ukierunkowanej na zachowanie jego tożsamości ${ }^{15}$. Analizując zatem kwestie związane z przepowiadaniem homilijnym i katechetycznym w kontekście regionalnym, na uwadze mamy „działalność zmierzającą do ciągłego ożywania, ubogacania, roz-

${ }^{9}$ H. Sławiński, Tematyczne programowanie przepowiadania homilijnego, „Roczniki Teologiczne" 62(2015) z. 2, s. 88.

${ }_{10}$ Zob. np. J. Kostorz, Zasada chrystocentryzmu w katechezie w świetle książki Benedykta XVI Jezus z Nazaretu, cz. I i II, „Studia Warmińskie” 48(2011), s. 137.

${ }^{11}$ DOK 253-264.

12 W. Broński, Przepowiadanie, w: Encyklopedia katolicka, t. 16, red. E. Gigilewicz, Lublin 2012, kol. 695.

${ }_{13}$ PDK 65-68.

${ }^{14}$ Zainteresowanych tymi kwestiami odsyła się do: H. Skorowski, Europa regionu. Regionalizm jako kategoria aksjologiczna, Warszawa 1999; S. Taboł, Regionalizm jako idea, ruch i dziatalność społeczno-kulturowa, „Pedagogika Przedszkolna i Wczesnoszkolna” 2015 nr 2, s. 89-96; M. Markocka, Regionalizm - wielość znaczeń i definicji, „Zeszyt Naukowy”, Międzynarodowe Centrum Dialogu Międzykulturowego i Międzyreligijnego. Uniwersytet Kardynała Stefana Wyszyńskiego w Warszawie 2014 nr 2, s. 30-37.

${ }^{15}$ H. Skorowski, Współczesne ujęcie regionalizmu, „Saeculum Christianum” 13(2006) nr 2, s. 177. 
woju, a także przekształcania tego wszystkiego, co w jakikolwiek sposób wiąże się z pojęciem wspólnoty, kultury i terytorium regionalnego, czyli tych wartości, jakie tkwią w regionie" ${ }^{\prime \prime}$. W tej działalności chodzi nie tylko o pielęgnowanie tradycji i dziedzictwa kulturowego regionu, ale także o ubogacanie jej, ożywianie, rozwijanie, tworzenie niejako na nowo czy też o propagowanie różnym społecznościom wartości w niej tkwiących oraz kształtowanie tożsamości regionalnej mieszkańców określonego terytorium. Obok ochrony materialnego i duchowego dziedzictwa kulturowego regionu, celem tej działalności jest aktywizacja społeczności lokalnej w różnych sferach życia (np. społecznego, kulturalnego, ekologicznego, gospodarczego, religijnego) i wspieranie mieszkańców regionu w kształtowaniu tożsamości regionalnej. Co ważne, tak określona działalność społeczno-kulturalna i organizacyjna sprzyja zarówno rozwijaniu i wzbogacaniu dziedzictwa kulturowego regionu oraz wprowadzaniu elementów kultury regionalnej do kultury kraju i ogólnoludzkiej, jak też kształtowaniu tożsamości regionalnej mieszkańców określonej społeczności lokalnej ${ }^{17}$.

\section{Kontekst regionalny a głoszenie słowa Bożego}

Wszyscy słuchacze słowa Bożego (np. podczas Mszy św. i różnych spotkań katechetycznych w parafii), mniej lub bardziej są zanurzeni w społeczności lokalnej, podlegają wpływom kultury regionalnej i inicjatywom podejmowanym w społeczności lokalnej czy też korzystają z wartości dziedzictwa kulturowego regionu, pielęgnują je lub dokonują ich rekonstrukcji, co ma wpływ na ich sposób myślenia oraz postrzegania rzeczywistości społecznej i kulturalnej ${ }^{18}$. Przekłada się to na podejście słuchaczy do tradycji i zwyczajów związanych z celebracją świąt i uroczystości roku liturgicznego (np. Bożego Narodzenia, Objawienia Pańskiego, Wielkanocy, Zesłania Ducha Świętego, Najświętszego Ciała i Krwi Chrystusa) oraz kultu Maryi i świętych. Oficjalne nauczanie Kościoła katolickiego od początku dostrzegało tę doniosłą rolę kultury, w tym także lokalnej ${ }^{19}$. Do odwoływania się w homilii i katechezie do kultury w jej wielorakich wymiarach zachęca Pismo święte, które jest bogate w przykłady bliskie kulturze ówczesnych słuchaczy i społeczności, w której żyli ${ }^{20}$. Ukazane w nich doświadczenia postaci biblijnych są przedstawiane językiem ich kultury ${ }^{21}$.

\footnotetext{
16 Tamże.

17 Tamże.

18 VD 109.

19 Zob. np. KDK 42, 58, 62; DE 4, 6; DV 110, 114; EN 20.

20 DV 110, 114.

21 Tamże.
} 
W ślad za tym podejmowana jest również refleksja na ten temat regionalizmu w Kościele ${ }^{22}$.

Obecnie, w nowych okolicznościach, gdy daje się zauważyć promocję dziedzictwa kulturowego „małych ojczyzn”23, kwestie regionalne wydają się ważne w przepowiadaniu homilijnym i katechetycznym. Tak homiliści, jak i katecheci muszą liczyć się z faktem, że głoszone przez nich słowo Boże winno być interpretowane w powiązaniu z kulturą, w której adresaci żyją i której wpływom podlegają. Nie mniej istotne są zainteresowania słuchaczy tym, co bliskie, bo związane z regionalnym dziedzictwem kulturowym i z „małą ojczyzną”. Pociąga to za sobą konieczność wsłuchiwania się w wiarę i pobożność ludową słuchaczy czy też wychodzenia od doświadczeń życiowych oraz interpretowania ich w świetle słowa Bożego ${ }^{24}$. Właśnie „w ludowej pobożności można dostrzec sposób, w jaki otrzymana wiara wcieliła się w jakiejś kulturze i dalej jest przekazywana. (...) Pobożność ludowa <<odzwierciedla (...) pragnienie Boga (...). [jest] cennym skarbem Kościoła katolickiego >>"25. Co więcej, w tego rodzaju pobożności są obecne elementy „kultury głęboko przemienionej przez ewangelię” ${ }^{26}$. W nich znajduje się „siła czynnie ewangelizująca"27, której homiliści i katecheci nie tylko, że nie mogą pomijać, ale winni ją docenić jako istotne źródło dobrych przykładów, które wzmacniają przepowiadanie słowa Bożego i pomagają słuchaczom w odkrywaniu wielkich dzieł Bożych oraz w przestrzeganiu w życiu zobowiązań płynących z wiary i przyjętych sakramentów ${ }^{28}$.

Każde zatem przepowiadanie chrześcijańskie - jak czytamy w „Dyrektorium homiletycznym”- „znajduje w sercu kultury ludu źródło wody żywej”29. To wła-

${ }^{22}$ Zob. np. H. Skorowski, Regionalizm w Kościele, Kościół w regionie, „Zeszyt Naukowy”, Międzynarodowe Centrum Dialogu Międzykulturowego i Międzyreligijnego. Uniwersytet Kardynała Stefana Wyszyńskiego w Warszawie 2014 nr 2, s. 15-29; T. Syczewski, Regionalizm w Kościele - Podlasie, „Zeszyt Naukowy”, Międzynarodowe Centrum Dialogu Międzykulturowego i Międzyreligijnego. Uniwersytet Kardynała Stefana Wyszyńskiego w Warszawie 2014 nr 2, s. 58-68.

${ }^{23}$ Zob. np. K. Denek(red.), Wokót matych ojczyzn, Szczecin 2013; R. Kantor, Regionalizm jako potencjalna odpowiedź na współczesne procesy globalizacji kultury, „Małopolska” 17(2015), s. 25 42; A. Pieczka, Dziedzictwo kulturowe regionu w działalności małopolskich bibliotek publicznych, „Małopolska” 19(2017), s. 171-181; H. Skorowski, Rola regionalnych towarzystw naukowych w podtrzymywaniu tradycji regionalnych, ,Studia Mazowieckie” 8(2013) nr 4, s. 117-133.

${ }^{24}$ Kongregacja ds. Kultu Bożego i Dyscypliny Sakramentów, Dyrektorium o pobożności ludowej i liturgii. Zasady i wskazania, Poznań 2003, 87-89, 91-92; zob. także: E. Wiszowaty, Pobożność ludowa w religijności policjantów i jej znaczenie pastoralne, „Ełckie Studia Teologiczne” 5(2004), s. $147-160$.
${ }^{25}$ EG 123.
26 Tamże 126.
27 Tamże.
28 Tamże; DH 10.
${ }^{29} \mathrm{DH} 8$. 
śnie kultura regionalna w jej wielorakich wymiarach może dostarczać homilistom i katechetom odpowiednich przykładów oraz właściwych sposobów przekazywania Ewangelii. Niewątpliwie każda osoba lubi, gdy mówi się do niej w jej języku ojczystym, gdy przekaz jest zrozumiały. Również słuchacze słowa Bożego preferują homilie i katechezy, podczas których mówi się do nich w kluczu kultury ojczystej i regionalnej, poprawną polszczyzną i regionalnym dialektem. „Wtedy serce przygotowuje się, by słuchać lepiej”30.

Sytuacja społeczeństwa, w którym - obok procesów globalizacji i pluralizmu kulturowego - daje się zauważyć zintensyfikowanie działalności zmierzającej do ciągłego ożywiania, ubogacania oraz rozwoju wspólnoty regionalnej i jej dziedzictwa kulturowego, domaga się, by w przepowiadaniu homilijnym i katechetycznym nie zostały przemilczane wartości kultury regionalnej, lecz oświetlone słowem Bożym. Między tymi dwiema rzeczywistościami nie ma bowiem sprzeczności. Przeciwnie, istnieje wzajemna współzależność. Urzeczywistnianie przepowiadanego podczas homilii lub katechezy słowa Bożego dokonuje się zawsze w konkretnym życiu osoby, która żyje, uczy się, pracuje, odpoczywa w określonej społeczności lokalnej i kulturze. Jednocześnie dowartościowanie kontekstu regionalnego w przepowiadaniu homilijnym i katechetycznym sprzyja „ewangelizacji pojmowanej jako inkulturacja"31.

\section{Treści kultury regionalnej w homilii i katechezie}

Współcześnie zarówno homilia, jak i katecheza potrzebują treści, które zdolne byłyby zaangażować, pobudzić, przekonać, rozwinąć i ukierunkować wiarę słuchaczy ${ }^{32}$. Pamiętając o tym, warto w przepowiadaniu homilijnym i katechetycznym - zgodnie z zasadą wierności Bogu i człowiekowi - odwoływać się do bogactwa chrześcijańskiego orędzia pozostającego w bezpośrednim związku z doświadczeniem i kulturą regionalną. Dobór tych zagadnień nie może być jednak przypadkowy. Zachodzi konieczność odpowiedniej selekcji materiałów, wyboru tych treści, które posiadają istotną wartość w omawianiu i interpretacji tekstów biblijnych, liturgicznych i katechizmowych. O tym, jakie treści zostaną wykorzystane w konkretnej homilii lub katechezie, decydują przede wszystkim czytania i modlitwy z danej celebracji liturgicznej lub temat katechezy. Obok tego ważna wydaje się również specyfika regionu, w którym homiliści i katecheci podejmują posługę przepowiadania słowa Bożego. Każdy bowiem region posiada swoiste cechy kultury lokalnej i sobie właściwe dziedzictwo kulturowe, które jest nośnikiem określonych wartości chrześcijańskich. Ukształtowało się

\footnotetext{
${ }^{30}$ Tamże; por. EG 139.

31 EG 122.

${ }^{32}$ PDK 65-66, 69-71; DH 7-8.
} 
ono na przestrzeni wieków. Z uwagi na procesy globalizacji często jednak regionalne dziedzictwo kulturowe traci swoją wartość, a społeczności lokalne zostają pozbawione swojej autonomii w sferze kultury. W Polsce są zarówno tereny, w których po II wojnie światowej nie została przerwana ciągłość kulturowa, jak też regiony, gdzie ciągłość uległa zerwaniu, a proces kształtowania nowej tożsamości przebiegał w oparciu o zastane dziedzictwo kulturowe i to, które ludność przyniosła $z$ innych terenów ${ }^{33}$. Dlatego otwarcie na aspekty regionalne i nawiązanie do wartości, których nośnikiem jest „mała ojczyzna”, wymaga od homilistów i katechetów nieustannego poszukiwania coraz właściwszych i znaczących dla słuchaczy treści, które są nośnikiem wartości duchowych, otwierają na Boga, uczą oceny kultury w świetle ewangelii oraz pomagają $\mathrm{w}$ interpretacji i przyjęciu przepowiadanego słowa Bożego ${ }^{34}$.

Wśród różnych zagadnień z zakresu kultury regionalnej, ujmowanej $\mathrm{w}$ jej wielorakich wymiarach, na uwagę homilistów i katechetów zasługują: zwyczaje i obrzędy (doroczne i rodzinne) związane z rokiem liturgicznym, dzieje rodzin zaangażowanych w życie Kościoła (zwłaszcza diecezji, parafii), osobowość świętych i wzorce osobowe związane bezpośrednio lub pośrednio $\mathrm{z}$ danym regionem, kult maryjny, świętych i błogosławionych w lokalnych sanktuariach oraz lokalna sztuka sakralna ${ }^{35}$. Znaczące wydają się również odniesienia do dzieł literatury regionalnej oraz różnych form apostolstwa, które osoby świeckie podejmowały w regionie na przestrzeni dziejów Kościoła ${ }^{36}$.

Warto też, zwłaszcza podczas katechez dla narzeczonych i rodziców chrzestnych, odwoływać się do lokalnych tradycji. Tego rodzaju zagadnienia są nośnikiem takich wartości, jak: Bóg, życie, dobro, prawda, piękno, sprawiedliwość, miłość, szacunek, odwaga, odpowiedzialność, patriotyzm. Odwołanie do tradycji regionalnych sprzyja też kształtowaniu postawy otwartości, dialogu i tolerancji wśród słuchaczy, zwłaszcza, gdy społeczność, w której żyją, jest mała, a zarazem wielokulturowa i naznaczona licznymi konfliktami, które mają swoje źródło w przeszłości. Jednocześnie przepowiadanie słowa Bożego w kontekście kultury regionalnej stwarza możliwość demaskowania różnego rodzaju zabobonów, guseł i przesądów, które są wyrazem fałszywego kultu religijnego i zaprzeczeniem autentycznej, osobowej wiary w Ducha Świętego, który działa w życiu osób wierzących ${ }^{37}$.

${ }^{33}$ Dla przykładu - do tych pierwszych zalicza się np. Podhale i Kaszuby, a wśród tych drugich wymienia się Mazury i Warmię, Śląsk. Zob. B. Jałowiecki, Oblicza polskich regionów, „Studia Regionalne i Lokalne" 50(1996), s. 19-88; Regiony etnograficzne w Polsce, http://naludowo.pl/ kultura-ludowa/regiony-etnograficzne-w-polsce-malopolska-slask-wielkopolska-pomorze-mapa-grupy-etnograficzne-zdjecie-opis.html [dostęp: 8.01.2018].

34 VD 109-110.

35 PDK 69-72; DOK 202-203.

36 PDK 69-72.

37 Kongregacja ds. Kultu Bożego i Dyscypliny Sakramentów, Dyrektorium o pobożności ludowej i liturgii. Zasady i wskazania, 65-66. 


\section{Sugestie homiletyczno-katechetyczne}

Dla pełniejszego rozumienia analizowanych w niniejszym opracowaniu kwestii ważny jest sposób przepowiadania homilijnego i katechetycznego. Głoszenie słowa Bożego w kontekście regionalnym wymaga bowiem nie tylko stałych, określonych formuł, precyzyjnych słów czy też języka właściwego dla adresatów i społeczności ${ }^{38}$, w której żyją, ale także różnych rozwiązań, które treściom absolutnie niezmiennym nadają dynamikę, sprawiają, że dla słuchaczy stają się one bliskie oraz poruszają serce i umysł, a przy tym skłaniają do osobistej refleksji3i. Niewątpliwie wolne tempo narracji rodzi znudzenie wśród słuchaczy. Potrzebna jest zatem odpowiednia dynamika, którą zarówno homilista, jak i katecheta mogą wykreować posługując się językiem zwięzłym, precyzyjnym, jasnym, obrazowym, pozytywnym, zrozumiałym dla słuchaczy ${ }^{40}$. Z tym wiąże się umiejętność przekazu w niewielu słowach wielu poruszających słuchacza treści, czemu służą krótkie, syntetyczne, logicznie uporządkowane, podejmujące jeden temat homilie i katechezy ${ }^{41}$. Nie może przy tym zabraknąć nie tylko przywoływania pozytywnych przykładów, ale także przemawiania obrazami ${ }^{42}$. „Atrakcyjny obraz sprawia, że przesłanie jest odczuwane jako coś swojskiego, bliskiego, możliwego do powiązania z (...) życiem, (...) budzi pragnienie i motywuje wolę ku Ewangelii'"43.

Uwzględniając sytuację egzystencjalną słuchaczy i jej powiązania z procesami społeczno-kulturowymi, jakie zachodzą w określonej społeczności, ważna wydaje się też umiejętność oświecania słowem Bożym doświadczeń słuchaczy oraz ich kultury bycia ${ }^{44}$. Chodzi tu o zdolność powiązania przesłania tekstu biblijnego przewidzianego na dany dzień roku liturgicznego, czyli czytań mszalnych, z sytuacją słuchaczy, z ich aktywnością społeczno-kulturalną, a zwłaszcza z zaangażowaniem w pielęgnowanie dziedzictwa kulturowego regionu ${ }^{45}$. To z kolei rodzi potrzebę otwartości homilistów i katechetów na wartości, jakich nośnikiem jest dziedzictwo kulturowe regionu oraz wrażliwości duchowej ${ }^{46}$.

38 Zainteresowanych tym zagadnieniem odsyła się do: M. Gadawa, Rola elementów regionalnych $w$ wybranych homiliach księdza Józefa Tisznera, „Polonia Sacra” 21(2017) nr 2, s. 121-142; L. Szewczyk, Na ambonie po Śląsku? Kontrowersje wokót głoszenia Słowa Bożego w dialektach i gwarach, „Śląskie Studia Historyczno-Teologiczne” 43/1(2010), s. 82-93.

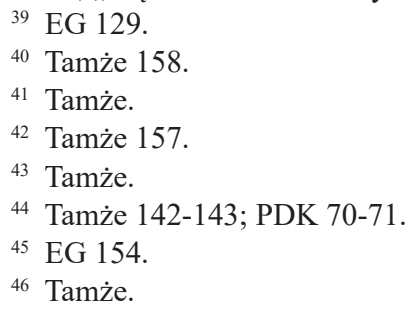


Właściwie rozumiane przepowiadanie homilijne rodzi również potrzebę ostrożności w stosowaniu „narzędzi aktywizujących, jakimi mogą być czasem nowoczesne formy techniczne (np. film, obraz, muzyka), a także rekwizyty (np. specjalne stroje itp.), aby środki te nie przysłaniały słowa, które powinno pozostać głównym środkiem komunikacji w homilii. W ocenie stosowności użycia takich środków podczas homilii należy mieć na względzie przede wszystkim świętość miejsca kultu Bożego" ${ }^{47}$. Z kolei w różnych formach duszpasterstwa katechetycznego w parafii warto zwrócić uwagę na ewangelizację, wtajemniczenie $\mathrm{w}$ misterium wiary, inicjację religijną oraz świadomy i aktywny udział $\mathrm{w}$ liturgii ${ }^{48}$. Domaga się to rezygnacji z rozwiązań dydaktycznych typowych dla lekcji religii w szkole na rzecz celebracji, medytacji słowa Bożego, ewangelicznej rewizji życia, lectio divina.

Autentyczna troska o właściwy sposób przepowiadania homilijnego i katechetycznego w kontekście regionalnym nie jest możliwa bez nieustannego otwierania się homilistów i katechetów na działanie Ducha Świętego. To właśnie Duch Święty jest najlepszym nauczycielem, który nie tylko pomaga odkrywać wartości dziedzictwa kulturowego danego regionu i interpretować je w świetle słowa Bożego, ale także podpowiada, jak głosić kerygmę ${ }^{49}$.

\section{Zakończenie}

Problematyka regionalizmu, na pierwszy rzut oka odległa od głoszenia słowa Bożego w formie homilii mszalnej i katechezy parafialnej, w istocie rzeczy może okazać się niezwykle pomocna w przekazie orędzia ewangelicznego. Jeśli zważymy, że duchowe dziedzictwo kulturowe regionu przeniknięte jest wartościami wyrosłymi na glebie tego orędzia, a zarówno homilista, jak i katecheta, jeśli chcą być słuchani, ciągle powinni mieć na uwadze słuchacza i jego horyzont życiowy. Uwzględnienie dziedzictwa kulturowego małych ojczyzn w przepowiadaniu, z jednej strony, może być skuteczną ilustracją, w jaki sposób wiara przenika tkankę codziennego życia i jest przekazywana dalej, z drugiej natomiast, w klimacie dominującej globalizacji, może służyć ochronie, pogłębieniu i rozwijaniu tego dziedzictwa. Jest rzeczą oczywistą, że zarówno właściwie rozumiana homilia, jak i katecheza, potrzebują treści, które zdolne byłyby zaangażować, pobudzić, przekonać, rozwinąć i ukierunkować wiarę słuchaczy. Wychodząc naprzeciw temu poszukiwaniu, Kościół katolicki od początku wskazywał na doniosłą rolę kultury, również w jej wymiarze lokalnym, podkreślając jednocześnie znaczenie

47 Wskazania Konferencji Episkopatu Polski dotyczace homilii mszalnych, http://www.diecezja. swidnica.pl/images/liturgia/Wskazania-KEP-dotyczce-homilii-mszalnej.pdf [dostęp: 11.01.2018].

${ }^{48}$ DOK 253, 257; CT 67.

${ }^{49}$ EG 165-166. 
pobożności ludowej, która, jako przejaw żywej wiary, stanowi ważny składnik tej kultury.

Zaprezentowane $\mathrm{w}$ artykule analizy nie pretendują do wyczerpującego przedstawienia zagadnienia. Mogą jednak stanowić inspirację do dalszych badań w tym zakresie oraz zachętę pod adresem homilistów i katechetów, by w realizacji swojej misji większą uwagę zwracali na to bogactwo, które zawiera w sobie dziedzictwo kulturowe „małych ojczyzn”.

\section{Homily and catechistic preaching in the regional context}

\section{Summary}

Every individual listening to the word of God, delivered either in the Holy Mass homily or parish catechesis, lives in a specific cultural environment, sometimes referred to as a "small homeland". It provides the "regional context" of preaching.

This paper presents the inspiring role of this "context" in contemporary preaching of the Gospel. In view of dominant globalization trends, this context seems to gain increasing importance. To avoid misunderstanding, the paper starts with presenting necessary definitions, such as the meaning of the term: "homily", "parish catechesis" or "regional context". Since the realization of the word of God delivered during the homily or parish catechesis always takes place in a specific life of an individual who lives, works or rests in a specific local community and who is immersed in its culture, the significance of this context in preaching the word of God is demonstrated. Additionally, the paper presents the content of the regional culture to be used both in the homily and in the parish catechesis.

In this context, homiletic and catechetical suggestions are indicated, among which the need for spiritual sensitivity and openness of homilists and catechists to the values of cultural heritage of the region comes to the fore.

\section{Keywords}

homily, catechesis, regionalism, regional culture, "small homeland", values

\section{Słowa kluczowe}

homilia, katecheza, regionalizm, kultura regionalna, „mała ojczyzna”, wartości

\section{Bibliografia}

Benedykt XVI, Adhortacja apostolska Verbum Domini o Słowie Bożym w życiu i misji Kościoła, Kraków 2010.

Broński W., Przepowiadanie, w: Encyklopedia katolicka, t. 16, red. E. Gigilewicz, Lublin 2012, kol. 694-695.

Denek K. (red.), Wokót małych ojczyzn, Szczecin 2013; R. Kantor, Regionalizm jako potencjalna odpowiedź na współczesne procesy globalizacji kultury, „Małopolska” 17(2015), s. 25-42.

Dyk S., Homilia - droga do żywego poznania misterium Chrystusa, Kielce 2016. 
Dyk S., Liturgia miejscem interpretacji słowa Bożego, „Zeszyty Naukowe Katolickiego Uniwersytetu Lubelskiego" 53(2010) nr 1, s. 33-46.

Gadawa M., Rola elementów regionalnych w wybranych homiliach księdza Józefa Tisznera, „Polonia Sacra" 21(2017) nr 2, s. 121-142.

Härtner A., Eschmann H., Predigen lernen. Ein Lehrbuch für die Praxis, Göttingen 2008.

Jałowiecki B., Oblicza polskich regionów, „Studia Regionalne i Lokalne” 50(1996), s. 19-88; Regiony etnograficzne $w$ Polsce, http://naludowo.pl/kultura-ludowa/regiony-etnograficzne-w-polsce-malopolska-slask-wielkopolska-pomorze-mapa-grupy-etnograficzne-zdjecie-opis. html [dostęp: 8.01.2018].

Jan Paweł II., Adhortacja apostolska o katechizacji w naszych czasach „Catechesi tradendae” (16.10.1979), w: Adhortacje Ojca Świętego Jana Pawła II, t. 1, Kraków 1996, s. 3-64.

Konferencja Episkopatu Polski, Dyrektorium katechetyczne Kościoła katolickiego w Polsce, Kraków 2001.

Kongregacja do Spraw Duchowieństwa, Dyrektorium ogólne o katechizacji (15.08.1997), tekst polski, Poznań 1998.

Kongregacja ds. Kultu Bożego i Dyscypliny Sakramentów, Dyrektorium Homiletyczne, Poznań 2015.

Kongregacja ds. Kultu Bożego i Dyscypliny Sakramentów, Dyrektorium o pobożności ludowej i liturgii. Zasady i wskazania, Poznań 2003.

Kostorz J., Zasada chrystocentryzmu w katechezie w świetle ksiązki Benedykta XVI Jezus z Nazare$t u$, cz. I i II, „Studia Warmińskie” 48(2011), s. 137-148.

Markocka M., Regionalizm - wielość znaczeń i definicji, „Zeszyt Naukowy”, Międzynarodowe Centrum Dialogu Międzykulturowego i Międzyreligijnego. Uniwersytet Kardynała Stefana Wyszyńskiego w Warszawie 2014 nr 2, s. 30-37.

Ojciec Święty Franciszek, Adhortacja apostolska Evangelii Gaudium o głoszeniu Ewangelii w dzisiejszym świeckie, Kraków 2013.

Paweł VI, Adhortacja apostolska o ewangelizacji w świecie współczesnym „Evangelii nuntiandi” (8.12.1975), tekst polski, Warszawa 1986.

Pieczka A., Dziedzictwo kulturowe regionu $w$ działalności małopolskich bibliotek publicznych, „Małopolska” 19(2017), s. 171-181.

Siwek G., Kiedy homilia, kiedy kazanie?, „Homo Dei” 76(2007) nr 4, s. 28-41.

Skorowski H., Europa regionu. Regionalizm jako kategoria aksjologiczna, Warszawa 1999.

Skorowski H., Regionalizm w Kościele, Kościót w regionie, „Zeszyt Naukowy”, Międzynarodowe Centrum Dialogu Międzykulturowego i Międzyreligijnego. Uniwersytet Kardynała Stefana Wyszyńskiego w Warszawie 2014 nr 2, s. 15-29.

Skorowski H., Rola regionalnych towarzystw naukowych w podtrzymywaniu tradycji regionalnych, „Studia Mazowieckie” 8(2013) nr 4, s. 117-133.

Skorowski H., Współczesne ujęcie regionalizmu, „Saeculum Christianum” 13(2006) nr 2, s. 157179.

Sławiński H., Tematyczne programowanie przepowiadania homilijnego, „Roczniki Teologiczne” 62(2015) z. 2, s. 77-91.

Sobór Watykański II, Dekret o ekumenizmie „,Unitatis redintegratio” (21.11.1964), w: Sobór Watykański II, Konstytucje, dekrety, deklaracje, tekst polski, nowe thumaczenie, Poznań 2002, s. 193-208.

Sobór Watykański II, Konstytucja duszpasterska o Kościele w świecie wspótczesnym „, Gaudium et spes” (7.12.1965), w: Sobór Watykański II, Konstytucje, dekrety, deklaracje, tekst polski, nowe thumaczenie, Poznań 2002, s. 526-606.

Sobór Watykański II, Konstytucja o liturgii świętej „,Sacrosanctum concilium” (4.12.1963), w: Sobór Watykański II, Konstytucje, dekrety, deklaracje, tekst polski, nowe tłumaczenie, Poznań 2002, s. 48-78. 
Syczewski T., Regionalizm w Kościele - Podlasie, „Zeszyt Naukowy”, Międzynarodowe Centrum Dialogu Międzykulturowego i Międzyreligijnego. Uniwersytet Kardynała Stefana Wyszyńskiego w Warszawie $2014 \mathrm{nr}$ 2, s. 58-68.

Szewczyk L., Na ambonie po Ślasku? Kontrowersje wokół głoszenia Słowa Bożego w dialektach i gwarach, „Śląskie Studia Historyczno-Teologiczne” 43/1(2010), s. 82-93.

Taboł S., Regionalizm jako idea, ruch i działalność społeczno-kulturowa, „Pedagogika Przedszkolna i Wczesnoszkolna" 2015 nr 2, s. 89-96.

Wiszowaty E., Pobożność ludowa w religijności policjantów i jej znaczenie pastoralne, „Ełckie Studia Teologiczne" 5(2004), s. 147-160.

Wiszowaty E., Przepowiadanie homilijne w społeczeństwie medialnym, „Roczniki Teologiczne” 61(2014) z. 6, s. 153-167.

Wskazania Konferencji Episkopatu Polski dotyczace homilii mszalnych, http://www.diecezja.swidnica.pl/images/liturgia/Wskazania-KEP-dotyczce-homilii-mszalnej.pdf [dostęp: 11.01.2018]. 